\title{
Degradation Study of Polypropylene (PP) and Bioriented Polypropylene (BOPP) in the Environment
}

\author{
Carina Longo, Michele Savaris, Mára Zeni, Rosmary Nichele Brandalise, Ana Maria Coulon Grisa* \\ Centro de Ciências Exatas e Tecnologia, Universidade de Caxias do Sul - UCS, \\ Rua Francisco Getúlio Vargas, 1130, CEP 95070-560, Caxias do Sul, RS, Brasil
}

Received: June 6, 2010; Revised: September 13, 2011

\begin{abstract}
Polymers are vastly employed for numerous purposes in different industrial segments and generate soaring quantities of discarding in the environment. This research analyzed the degradability/biodegradability of polypropylene films (PP) and Bioriented polypropylene (BOPP) polymers after 11 months interred in the São Giácomo landfill in Caxias do Sul. Comparing the buried PP film to a sample of virgin PP, two peaks of degrading activity appeared at the TG curve as well as structure modification typified by occurrence of new absorption bands at FTIR, which can be credited to changes in crystallinity. Thermal analysis carried out on the buried PP and BOPP showed decreases in the percentage of crystallinity due to chain scission. The major reduction was observed in the PP, since its crystallinity is a consequence of polymerization instead of chain orientation processes, as in BOPP. Cracks and erosion of the polymer surface were detected in both PP and BOPP, indicating degrading processes by microorganisms.
\end{abstract}

Keywords: polypropylene, bioriented polypropylene, degradation, landfill

\section{Introduction}

Amongst the various components of waste in landfills, polymeric materials composites account for an estimated 20 to $30 \%$ of the total volume of solid waste disposed. Since polymeric materials are immune to microbial degrading, they remain in the soil and in landfills as a semi-permanent residue. Polymeric discard is, admittedly, one of the most challenging classes of waste to dispose of, in such a degree that its discarding is being blamed for shortening the life span of a sanitary landfill ${ }^{1}$.

The total mass of solid waste from the selective waste collection in the town of Caxias do Sul-RS, was of $17.3 \%$ in 2003 (ZATTERA et al., 2007), while the quantities concerning the percentage of polymeric post-consumption discards rigid PP packaging accounted for an average of $7.46 \%{ }^{[2]}$.

Polypropylene films (PP) and Bioriented Polypropylene (BOPP) are widely used in packaging and in a variety of other applications due to their great potential in terms of barrier properties, brilliance, dimensional stability and processability. As the use of the material widens so does the amount of waste disposed of into the environment ${ }^{3-4}$.

PP film orientation is a physical process in which the polymer molecular chains go through an orientation process that allows the making of extremely thin film, maintaining at the same time properties suitable for handling and conservation, namely tensile strength, material firmness, brilliance, silkiness and, in the case of semicrystalline polymers such as $\mathrm{PP}$, a significant reduction in permeability to gases and vapor of about $50 \%$, according to the temperature degree in which the orientation was performed ${ }^{5}$.

Once in the environment, plastic waste is subjected to solar radiation, UV rays and heat, which affect their surface as well as to some extent their bulk properties. This deterioration or degradation process, however, is extremely slow ${ }^{6}$. The primary step for instigating this biodegradation process would be attaching a microorganism to the polymer surface, thus creating a biofilm ${ }^{7}$. Nonetheless, PP shows resistance to biodegradation since it is highly hydrophobic, has high molecular weight, lacks of an active functional group and has a continuous chain of repetitive methylene units ${ }^{8}$.

Degrading of polymeric waste in a sanitary landfill may occur by one or more of the above mentioned processes, which can happen simultaneously ${ }^{9-10}$.

During the process of polymeric materials degradation oxygen diffusion occurs prevalently in the amorphous regions, linking degradability to the thermal history of the material, in addition to synthesis faults (start of degradation in preferential sites and chromophores, as is the case of carbonyls and unsaturated carbons) which do not belong in the crystalline structure, but are rather part of the amorphous region ${ }^{11}$.

PP amorphous regions are the most susceptible to degradation and the impurities in the polymeric material can act as a catalyst for photodecomposition ${ }^{12}$. The energy absorbed by means of heat, light, mechanical strain, etc. cause $\beta$-scission, and peroxide and hydroperoxides radicals generated catalyze the process ${ }^{13-16}$.

Due to the presence of hydrogen linked to a tertiary carbon in the backbone chain, polypropylene degrades preferentially by chain scission with an overall shift of the molecular weight distribution curve towards lower values ${ }^{17}$.

Reports on biodegradation of PP are very scarce, although considerable literature addresses the biodegradation of low and high density polyethylene ${ }^{18-19}$. Fungal species (Aspergillus Niger) and microbial communities including Pseudomonas and Vibrio species have been reported to biodegrade $\mathrm{PP}^{20}$.

During microbial activity the microorganisms release protein structures, called enzymes, responsible for metabolism or transformation/breakdown of a substance into another ${ }^{21}$.

The microorganisms participating in the degrading process attack the surface and settle in a biofilm-like colony, which produce alterations as it comes into contact with the polymer ${ }^{22}$. Biofilms 
are embedded in the polymer at source, consisting basically of extracellular polysaccharides, proteins and microorganisms ${ }^{21-22}$. In general, bacteria, fungi, alga and protozoa may be identified in biofilms.

The formation of biofilms is a prerequisite to substance corrosion and/or material deterioration. Some polymers are susceptible to direct biodegradation via enzymes and/or microorganisms, while others may allow degrading only after a hydrolytic stage or scission of the oxidant chain ${ }^{23}$.

This report presents a study on degradability/biodegradability of PP and BOPP polymeric films in sanitary landfill environment, buried at a two meter depth during an 11 month period.

\section{Material and Methods}

\subsection{Experimental}

\subsubsection{Preparation of the specimens}

Samples used were polypropylene film (PP) and bioriented polypropylene (BOPP) that were available at local stores. The following coding was set for each group: virgin $\mathrm{PP}(\mathrm{PPv})$; buried $\mathrm{PP}$ (PPa); virgin BOPP (BOPPv) and buried BOPP (BOPPa).

The samples of transparent PP and BOPP film, both approximately $5 \mu \mathrm{m}$ thick, in triplicate, $10 \times 10 \mathrm{~cm}$, were washed before and after burial in the landfill with a $7 \%$ sodium hypochlorite $(\mathrm{NaClO})$ solution during 30 minutes, according to ASTM D6288-89 ${ }^{[24]}$, then dried up in desiccators for 24 hours.

Both PP and BOPP samples were placed in polyethylene grid involucres of 13 meshes $(28 \times 20 \mathrm{~cm})$ and, later, buried $2 \mathrm{~m}$ deep at the location $\mathrm{C} 10$ in the São Giácomo landfill, which began receiving domestic waste in 2002, in the town of Caxias do Sul (Figure 1).

Caxias do Sul coordinates are $29^{\circ} 10^{\prime} 25^{\prime}$ "South and $54^{\circ} 12$ ' $21^{\prime}$ "West, $760 \mathrm{~m}$ above sea level. The area called "São Giácomo landfill" (Figure 2) is property of the Municipality of Caxias do Sul, RS, Brazil, and within Brazilian norms (NBR 8418/1984 and NBR $8419 / 1984)^{[25]}$ for disposal of solid waste in landfill cells. From 1988 to 1990 the landfill was host to disorderly dumped solid waste of multiple urban and industrial sources produced in the municipality, causing environmental damage to an area of approximately $1.4 \mathrm{ha}^{26}$. The landfill no longer receives domestic solid waste. $\mathrm{C} 10$ cell was the last site planned; now 5 years-old and in the methanogenic phase ${ }^{27}$.

\subsection{Analysis}

\subsubsection{Thermogravimetric Analysis (TGA)}

Thermogravimetric analysis was carried out by a TA thermo gravimetric analyzer (DSC-60 Shimadzu). The $10 \mathrm{mg}$ of the samples were scanned from 25 to $900{ }^{\circ} \mathrm{C}$ at a heating rate of $10^{\circ} \mathrm{C} / \mathrm{min}$ in the presence of nitrogen.

\subsubsection{Differential Scanning Calorimeter (DSC)}

The melting and crystallization behavior of the composites were studied using a differential scanning calorimeter (DSC-60 Shimadzu) according to the ASTM D3418-08 ${ }^{[28]}$ standards, equipped with a cooling attachment at $50 \mathrm{~mL} \cdot \mathrm{min}^{-1}$ count flow under nitrogen atmosphere. The data were collected by heating the composite specimen from 25 to $200{ }^{\circ} \mathrm{C}$ at a constant heating rate of $10^{\circ} \mathrm{C} / \mathrm{min}$ and approximately $5.0 \mathrm{mg}$ mass.

The percentage of crystallinity was calculated from the melting enthalpy $(\Delta \mathrm{Hm})$ using the following formula: the enthalpy of $100 \%$ crystalline polypropylene $\left(\Delta \mathrm{Hm}^{\circ}\right)$ is $207 \mathrm{~J}^{-\mathrm{g}^{-1}}$ and is used as reference.

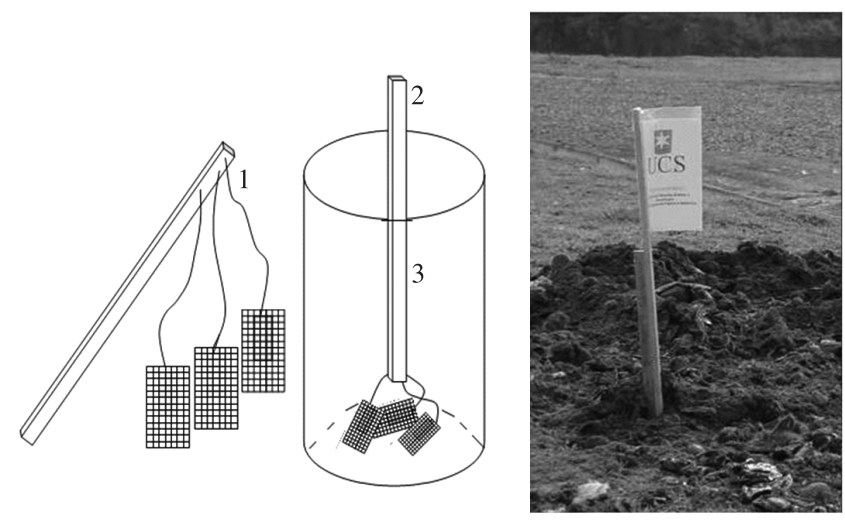

Figure 1. Ilustration of method used for PP and BOPP film disposal at the C10 cell in the São Giácomo sanitary landfill.

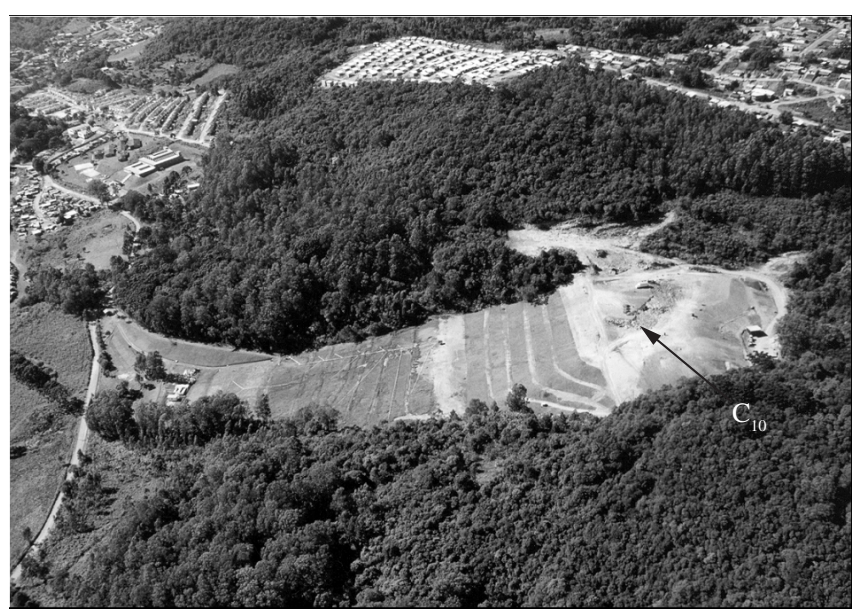

Figure 2. Aerial view of São Giácomo C10 landfill.

$$
\% \text { Crystallinity }=\left(\frac{\Delta H m}{\Delta H m^{\circ}}\right) \times 100
$$

Where: $\Delta \mathrm{Hm}$ polymer $=$ polymer enthalpy of fusion as in the thermogram, in $\mathrm{J} \mathrm{g}^{-1} ; \Delta \mathrm{Hm}^{\circ}=$ enthalpy of fusion of PP, $100 \%$ crystalline, correspondent to $207 \mathrm{~J} \mathrm{~g}^{-1[29]}$.

\subsubsection{Fourier Transform Infrared (FTIR) spectroscopy analysis}

Fourier Transform Infrared (FTIR) Spectroscopy is a tool for identifying various functional groups present in a compound. The analysis was performed using a Spectrum 2000 - Perkin Elmer 4000 to $400 \mathrm{~cm}^{-1}$ fed with film-sheet samples.

Formation or disappearance of functional groups in the polymer during the process of degradation can be monitored by FTIR $^{30-31}$. Double $\mathrm{C}=\mathrm{C}$ bonds can be observed on the spectrum at $1645 \mathrm{~cm}^{-1}$. The double bond is generated by thermo-oxididative decomposition of the hydroperoxides during thermo mechanic excitement of the chain ${ }^{32}$.

During the degradation process several aspects were monitored: the carbonyl group region present between 1700 and $1800 \mathrm{~cm}^{-1[33]}$, the changes in relative absorbance intensity of the ketone group (IK), (corresponding to $1715 \mathrm{~cm}^{-1}$ or $1711 \mathrm{~cm}^{-1}$ ), the methyl group (IM) (corresponding to $1377 \mathrm{~cm}^{-1}$ ) to that of the methylene group (at $1456 \mathrm{~cm}^{-1}$ ), as well as the isotacticity (ISO) (997 and $973 \mathrm{~cm}^{-1}$ ) 
of the polymer ${ }^{34}$. The absorbance intensity value corresponding to the methylene group bending was used as standard, since it was supposedly unchanged for the duration of the study.

The following equations were used for index calculation.

$$
\begin{aligned}
& \text { Methylene group IM }=\frac{A_{1377}}{A_{1456}} \\
& \text { Isotacticity ISO }=\left(\frac{A_{997}}{A_{973}}\right) \times 100
\end{aligned}
$$$$
\text { Ketone carbonyl index } I K=\frac{A_{1715}}{A_{1456}} \text { or } \frac{A_{1711}}{A_{1456}}
$$

\subsubsection{Scanning Electron Microscopy (SEM) and Optical Microscopy (MO)}

The morphology of PP and BOPP films was observed using a scanning electron microscope (SEM) at room temperature and metalized with Au. A JEOL (model JSM- 5800) SEM with field emission gun and accelerating voltage of $10 \mathrm{kV}$ was used to collect SEM images of the samples.

Optical microscopy (MO) on the samples was carried out on a Nikon Epiphot 200.

\section{Results and Discussions}

Thermogravimetric analysis (TGA) was used to verify thermal decomposition of polyolefin ${ }^{35-36}$. TG/DTG is capable of identifying changes in crystallinity, carbon chain scission and crosslinking ${ }^{37}$. The results obtained via TG analysis on PP and BOPP film both virgin and buried are showed on Table 1 .

During the analysis of the thermal details, two mass loss events could be observed for the PPa when compared to the PPv. According to Suat et al. $(2008)^{38}$, thermal degrading of PP residues takes place in two different stages of mass loss occurring in the temperature range between 310 and $475^{\circ} \mathrm{C}$. At this step, total weight loss of the waste PP was found to be $99.30 \mathrm{wt}$. (\%) which shows that the decomposition of the waste PP occurred. The inflection point (where the rate of weight

Table 1. Thermogravimetric analysis (TGA) of the PP and BOPP films $\left(10{ }^{\circ} \mathrm{C} / \min\right.$ in $\left.\mathrm{N}_{2}\right)$.

\begin{tabular}{ccc}
\hline Sample & Temperature $\left({ }^{\circ} \mathrm{C}\right)$ & Weight loss $(\%)$ \\
\hline $\mathrm{PPv}$ & 450.9 & 35.4 \\
$\mathrm{PPa}$ & 294.4 & 62.9 \\
& 463.8 & 25.7 \\
$\mathrm{BOPPv}$ & 447.4 & 35.8 \\
$\mathrm{BOPPa}$ & 451.4 & 32.7 \\
\hline
\end{tabular}

Table 2. Results of thermal analysis via DSC.

\begin{tabular}{ccccccc}
\hline Sample & $\begin{array}{c}\text { T. on set } \\
\left({ }^{\circ} \mathrm{C}\right)\end{array}$ & $\begin{array}{c}\mathrm{Tm} \\
\left({ }^{\circ} \mathrm{C}\right)\end{array}$ & $\begin{array}{c}\text { Xc } \\
(\%)\end{array}$ & $\begin{array}{c}\mathrm{T} \text {. on set } \\
\left({ }^{\circ} \mathrm{C}\right)\end{array}$ & $\begin{array}{c}\mathrm{Tm} \\
\left({ }^{\circ} \mathrm{C}\right)\end{array}$ & $\begin{array}{c}\mathrm{Xc} \\
(\%)\end{array}$ \\
\hline PP v & 150.7 & 166.7 & 41.2 & 157.0 & 166.2 & 44.1 \\
PP a $^{\circ}$ & 135.5 & 153.7 & 33.3 & 131.0 & 156.9 & 32.6 \\
BOPP v & 153.1 & 168.1 & 37.7 & 156.1 & 167.7 & 39.4 \\
BOPP a & 158.4 & 168.7 & 34.6 & 154.9 & 165.4 & 37.5 \\
\hline
\end{tabular}

$\mathrm{T}=$ temperature. loss is maximum) on the TG curve for the waste PP was found to be $454{ }^{\circ} \mathrm{C}$, similar to the results found in this study.

When compared to PP films, commercial BOPP films have dissimilar proprieties given the peculiar process of chain orientation. This singularity, however, makes the BOPP structure less subject to microbial attack and, consequently, biodegradation ${ }^{38}$, and does not reflect in maximum degrading temperature increase when compared to $\mathrm{PPv}$. Results obtained concerning mass loss on BOPPv samples are similar to the PPv films, but dissimilar for the buried samples, showing that BOPP chain orientation interferes in its thermal degradation.

Table 2 presents results of thermal analysis obtained via DSC and the crystallinity percentage values.

DSC analysis resulted in BOPP melting temperature $(\mathrm{Tm})$ higher than PP Tm melting temperature, which may be due to the polymer chain orientation. A reduction in the percentage of crystallinity (Xc) of the buried polymers was observed, which is confirmed also by Chawla et al. ${ }^{39}$.

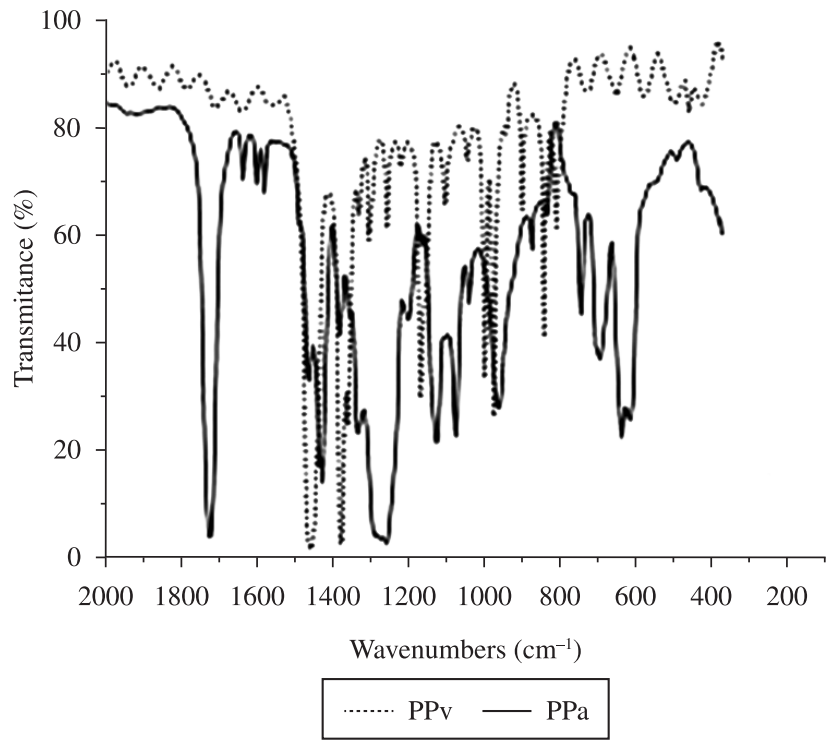

(a)

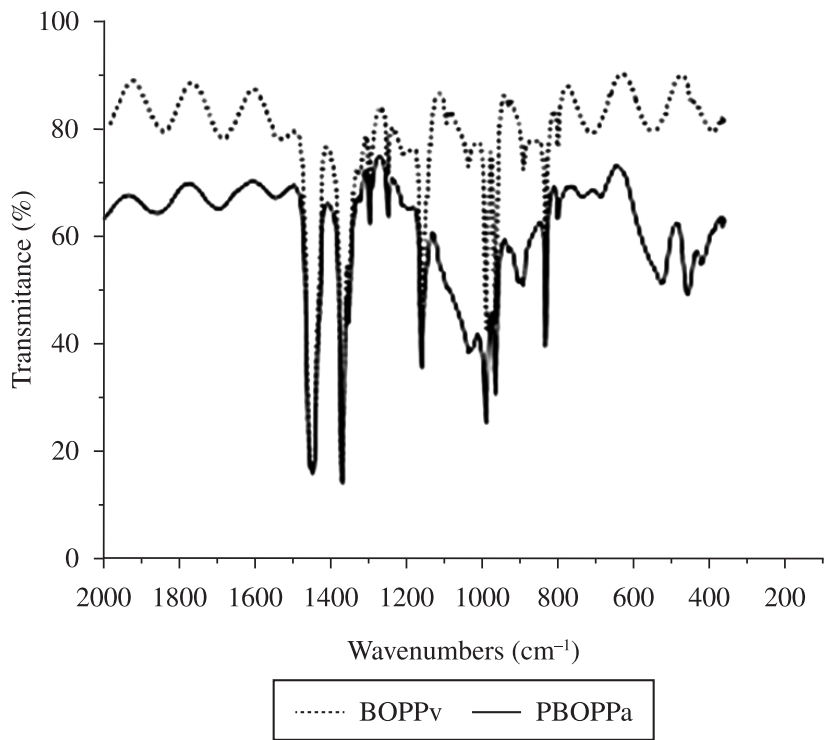

(b)

Figure 3. FTIR Spectroscopy on samples a) PPv and PPa; b) BOPPv and $\mathrm{BOPPa}$ before and after burial in the landfill. 
In the polymer biodegradation process, namely by access of microorganisms to its amorphous regions, higher crystallinity results are to be expected. Depending on duration of exposure, chain oxidation and occurrence of chain scission, however, the crystallinity lessens. Higher crystallinity loss was detected in the PP when compared to BOPP after being buried, since such polymer has its crystallinity oriented by physical process and not as a result of polymerization.

Chawla et al. (2006) credits changes in crystallinity in the polymers to reductions in molar mass, probably due to chain $\beta$-scission ${ }^{32-39}$. The decrease in the degree of crystallization due to biodegradation suggests that smaller crystals were formed ${ }^{40,41}$. Significant changes in crystallinity are visible, considering regions

Table 3. FTIR analysis of the ketone group (IK), the methyl group (IM), and samples isotacticity (ISO) results.

\begin{tabular}{cccc}
\hline Samples & IK $(\%)$ & IM (\%) & ISO (\%) \\
\hline PPv & 0.04 & 0.32 & 77.88 \\
PPa & $\mathrm{Ni}$ & $\mathrm{Ni}$ & 33.33 \\
BOPPv & 0.29 & 0.79 & 67.91 \\
BOPPa & 0.16 & 0.68 & 79.25 \\
\hline
\end{tabular}

$\mathrm{Ni}=$ not identified in the spectrum.
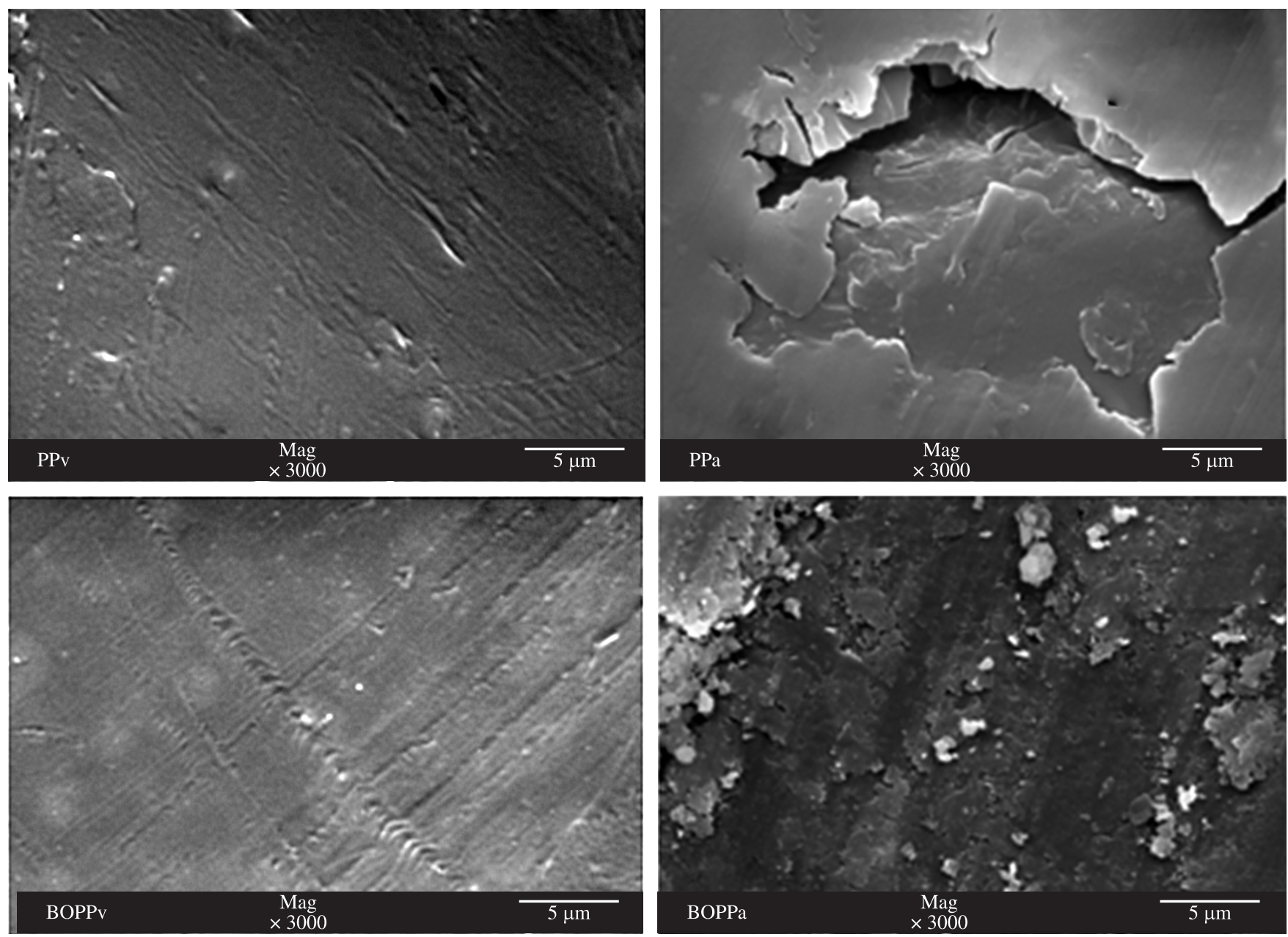

between 900 and $800 \mathrm{~cm}^{-1}$ range, due to polymeric chain scission of buried PPa and BOPPa.

Fourier Transform Infrared (FTIR) Spectroscopy was utilized to identify various functional groups that emerged in the samples, as well as the disappearance of determinate groups ${ }^{42,43}$.

Structural analysis on transparent $\mathrm{PPv}, \mathrm{PPa}, \mathrm{BOPPv}$ and $\mathrm{BOPPa}$ films retrieved from the landfill after 11 months burial showed new absorption regions, displayed in Figure 3.

The spectrum on PPa film (Figure 3a) showed evidence of new absorbance bands at $1723(-\mathrm{C}=\mathrm{O}), 1636,1465\left(-\mathrm{CH}_{2}\right), 1425\left(-\mathrm{CH}_{2}\right)$, 1257, 1124 (-CH), 1074 (-C-O-C-), 1040 (cyclical -C-O-C), 872, $741\left(-\mathrm{C}=\mathrm{CH}_{2}\right), 695$ and $614 \mathrm{~cm}^{-1}$ regions.

Luongo (1960) found that measures of crystallinity or isotacticity of the polypropylene tapes relating to the fraction of ordered monomeric repeat units present in isotactic polypropylene were also calculated from the respective ratios of optical intensities of crystalline absorption bands at 998 and $974 \mathrm{~cm}^{-1[44]}$.

Presence of the carbonyl group at $1722 \mathrm{~cm}^{-1}$ may be associated to degrading mechanisms more evident in the buried PPa. Similar results were found by Grisa and Zeni (2008) in a study on PP degradation in the sanitary landfill, Cell C3, at $9 \mathrm{~m}$ depth ${ }^{37}$.

The incidence of absorbance measured in the regions 872,741 , 695 and $614 \mathrm{~cm}^{-1}$ may possibly signal changes in crystallinity on the buried PP.

Figure 4. Micrographic (SEM) picture of the samples before and after burial in the landfill. 

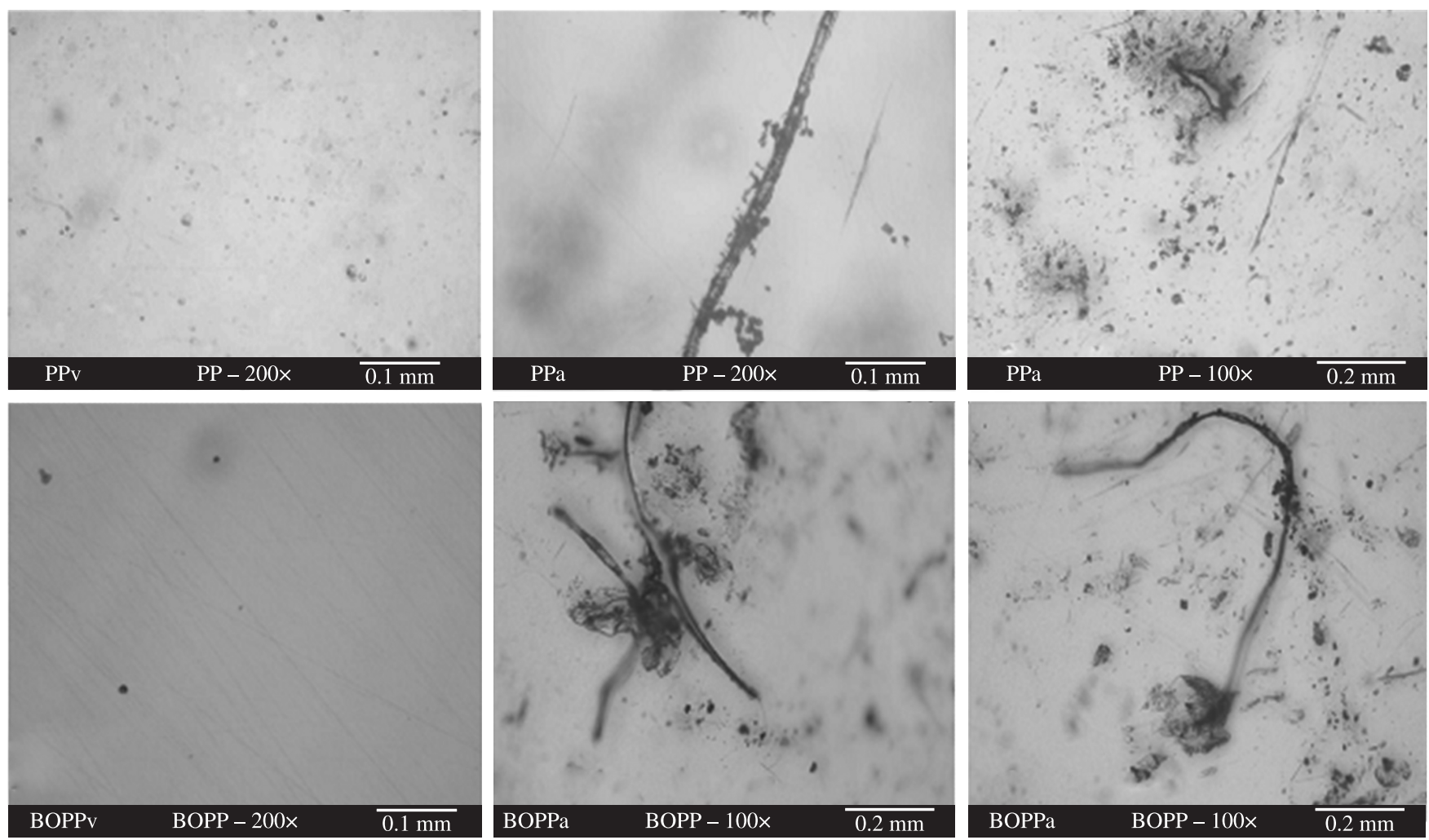

Figure 5. Micrography $(\mathrm{OM})$ of the samples showed evidence of microorganism adherence.

FTIR analysis of BOPPa film indicate the prevalence of new bands at 1043 (cyclical -C-O-C), 912, 750 and $695 \mathrm{~cm}^{-1}\left(-\mathrm{C}=\mathrm{CH}_{2}\right)$ regions. Strains on 912,750 and $695 \mathrm{~cm}^{-1}$ regions are related to changes in crystallinity for BOPPa film originated from polymeric chain scission ${ }^{36}$.

FTIR BOPPv film 1304, 1120, 1103, 940, 899 and $809 \mathrm{~cm}^{-1}$ spectrum bands belong to the group of regularity bands, and are related to different helix lengths of isotactic sequences ${ }^{43,44}$. However, the peaks at 973,1377 , and $1454 \mathrm{~cm}^{-1}$ represent segments residing predominantly in the amorphous region ${ }^{44}$. These bands and peaks indicate that the BOPPv film was made from isotactic PP. During the same 12 month period of burial, the isoacticity (ISO) calculated through FTIR, increased from 79 to $87 \%$ for $\mathrm{PP}^{34}$, similar to values observed in this study for BOPP. These findings are visible in the column where the higher \% ISO values are shown in the Table 3, together with results from the ketone group (IK), methyl group (IM) gathered from the samples.

The alignment of polymer chains in oriented materials facilities the formation of crystalline structures, resulting in higher crystallinity. The covalent bonds between carbon atoms in polypropylene carbon chains, together with orientation, increase the number of polypropylene chains aligned towards the stretching ${ }^{45}$.

PP has three carbon atoms in the chain where radicals can form namely, at primary (methyl group), secondary (in the chain, not attached to methyl group) and/or tertiary position (in the chain to which the methyl group is attached). Iring and Tudos (1990) suggested that the primary alkyl radical may be formed due to the oxidation of the tertiary carbon ${ }^{46}$.

In this study the PPv showed low IK values, and peaks around $1720-1730$ and $1640 \mathrm{~cm}^{-1}$ were no longer detected after burial, given the biodegradation process. Similar results were found observing
BOPPa. Peaks around $1720-1730$ and $1640 \mathrm{~cm}^{-1}$ regions may be due to groups of carboxylic of ester and aldheyde or ketone or even to the presence of double bonds ${ }^{47}$. According to Arkatkar et al. $(2010)^{48}$, the formation of the keto carbonyl and the ester carbonyl groups indicate oxidation of the polymer. Formation of carbonyl groups $\left(1723 \mathrm{~cm}^{-1}\right)$ by means of sample oxidation in the landfill stimulates microorganisms to initiate the biodegrading process.

The absorbance at $1377 \mathrm{~cm}^{-1}$ is because of the methyl group, and in the present study its intensity decreases as a function of time (11 months buried in the landfill), which indicates that the oxidation takes place at the primary position of the polymer chain.

Micrographic results of PP and BOPP films (Figure 4) extracted from the sanitary landfill showed the formation of pits and cracks on the polymeric surface, which are typical events associated to the biodegradation process. According to Arkatkar $(2010)^{48}$, the ability of a microorganism to utilize any substrate depends on its growth and its adherence to form a biofilm.

Optical micrography on PP and BOPP after disposal shows evidence of microorganism adherence (Figure 5) visible as chromatic alteration and surface rupture of the polymeric material. According to Fleming (1998), the color spectrum observed in the cracks and in the colony of microorganisms is caused by excretion of microbial lipophylic pigments, brining evidence of biodegradation process in the polymer ${ }^{22}$.

\section{Conclusions}

The conclusions outlined below present the major effects on samples buried for 11 months at a 2 m depth in the sanitary landfill.

Thermal analysis on PP and BOPP buried polymers showed reduction in the percentage of crystallinity, and this occurrence was 
credited to chain scission. Higher crystallinity loss was observed on $\mathrm{PP}$ where crystallinity is the result of polymerization, than in BOPP where it is a result of chain orientation processes.

Chemical analysis via FTIR spectrometry demonstrated that buried PP and BOPP films experienced structural alterations, for instance increase in the index of ketone groups, indicating oxidation of the polymer and increase of double bonds intensity showing evidence of degradation by means of $\beta$ scission of the polymer chain.

SEM and OM revealed the start of degradation/biodegradation processes of the polymeric film in the landfill typified by microorganism colonies on the polymer surface, chromatic alteration and formation of cracks.

\section{Acknowledgements}

The Authors are grateful to the CNPq, FAPERGS and the University of Caxias do Sul (UCS) for the financial support.

\section{References}

1. Matos TFL and Schalch V. Composição dos Resíduos Poliméricos, PósConsumo Gerados no Município de São Carlos, SP. Polímeros. 2007; 17(4):346-351.

2. Zattera AJ, Carli LN, Poletto M and Schneider VE. Avaliação Preliminar da Incidência de resíduos poliméricos provenientes da coleta seletiva no município de Caxias do Sul. In: Anais do $9^{\circ}$ Congresso Brasileiro de Polímeros; 2007; Campina Grande. Sao Paulo: Associação Brasileira de Polímeros; 2007.

3. Majumda J, Cser F, Jollands MC and Shanks RA. Thermal Properties of polypropylene post-consumer waste (PP PCW). Journal of Thermal Analysis and Calorimetry. 2004; 78:849-863,

4. Marcilla A, Gomez A, Reyes-Labarta JA and Giner A. Polymer Degradation Stability. 2003; 80:233-240. http://dx.doi.org/10.1016/ S0141-3910(02)00403-2

5. Mrkic S, Galic K and Ivankovic M. Effect of Temperature and Mechanical tress on Barrier Properties of Polymeric Films Used for Food Packaging. Journal of Plastics Film and Sheeting. 2007; 23:239. http://dx.doi. org/10.1177/8756087907086102

6. Suits LD and Hsuan YG. Assessing the photo-degradation of geosynthetics by outdoor exposure and laboratory weatherometer. Geotextiles and Geomembranes 2003; 21:111-122. http://dx.doi.org/10.1016/S02661144(02)00068-7

7. Hadad D, Geresh S and Sivan A. Biodegradation of polyethylene by the thermophilic bacterium Brevibacillus Borstelensis. Journal of Applied Microbiology. 2005; 98:1093-1100. http://dx.doi.org/10.1111/j.13652672.2005.02553.x

8. Arkatkar A, Arutchelvi J, Sudhakar M, Bhaduri S, Uppara PV and Doble M. Approaches to enhance the biodegradation of polyolefins. The Open Environmental Engineering Journal. 2009; 2:68-80. http://dx.doi. org/10.2174/1874829500902010068

9. Gu J-D. Microbiological deterioration and degradation of synthetic polymeric materials: recent research advances. International Biodeterioration and Biodegradation. 2003; 52:69-91. http://dx.doi. org/10.1016/S0964-8305(02)00177-4

10. Albertsson AC and Karlsson, S. Aspects of biodeterioration of inert and degradable polymers. International Biodeterioration and Biodegradation. 1993; 31:161-170. http://dx.doi.org/10.1016/0964-8305(93)90002-J

11. Ogier L, Rabello MS and White JR. Influence of morphology and surface preparation on the weatherability of polypropylene, Journal of Materials Science. 1995; 30(29):2364-2376. http://dx.doi.org/10.1007/BF01184588

12. Severine F, Gallo R and Ipsale S, Some aspects of the environmental photo-degradation of LDPE. Polymer Degradation Stability. 1998; 22(1):53-61. http://dx.doi.org/10.1016/0141-3910(88)90056-0

13. Billingham NC and Calved PD. An Introduction-Degradation and Stabilization of Polyolefins. London: Aplied Science Publishers; 1983.
14. Hinsken H, Moss S, Pauquet JR and Zweifel H. Degradation of polyolefins during melt processing. Polymer Degradation Stability. 1991; 34(1-3):279-293. http://dx.doi.org/10.1016/0141-3910(91)90123-9

15. Kelen T. Polymer Degradation. Van nostrad Reinhold. New York: United States; 1983.

16. Whiteeley KS, Heggs TG, Koch H and Mawer RL. Polyolefins. In: Ullmann's Encyclopedia of Industrial Chemistry. New York: Elsevers, VCH; 1982. 487 p.

17. Canevarolo SV. Chain scission distribution function for polypropylene degradation during multiple extrusions. Polymer Degradation and Stability. 2000; 709:71-76. http://dx.doi.org/10.1016/S01413910(00)00090-2

18. Premraj R and Doble M. Biodegradation of polymers. Indian Journal of Biotechnology. 2005; 4:186-193.

19. Arutchelvii J, Sudhakar M, Arkatkar A, Doble M, Bhaduri S and Uppara PV. Biodegradation of polyethylene and polypropylene. Indian Journal of Biotechnology. 2008; 7:9-22.

20. Cacciari I, Quatrini P, Zirletta G, Mincione E, Vinciguerra V, Lupatelli P et al. Isotactic polypropylene biodegradation by a microbial community: physicochemical characterization of metabolites produced. Applied and Environmental Microbiology. 1993; 59:3695-3700.

21. Vazzoler RF. Microbiologia e Saneamento Ambiental. EdUSP; 2001

22. Fleming H-C. Relevance of biofilms for the biodeterioration of surfaces of polimeric materials. Polymer Degradation and Stability. 1998; 59:309-15. http://dx.doi.org/10.1016/S0141-3910(97)00189-4

23. Albertsson AC and Karlsson S. Macromolecular Architecture-Nature as a Model for degradable polymers. Journal of Macromolecular Science, Part A: Pure Applied Chemistry. 1996; 33(10):1571-1579. http://dx.doi. org/10.1080/10601329608014926

24. American Society for Testing Materials - ASTM. D-6288-98: Standard Practice for Separation Washing of Recycled Plastics Prior Testing. ASTM; 1998.

25. Associação Brasileira de Normas Técnicas - ABNT. NBR 8418/1984: Apresentação de projetos de aterros de resíduos industriais perigosos Procedimento Associação Brasileira de Normas Técnicas. ABNT; 1984.

26. Teixeira CE, Mandelli SMC, Pessin N and Brustolin I. Monitoramento ambiental e do processo de remediação de área degradada por resíduos sólidos urbanos do aterro sanitário de São Giácomo, Caxias do Sul. In: Anais do Simpósio Internacional de Qualidade Ambiental; 1996; Porto Alegre. Porto Alegre: PUCRS; 1996.

27. Grisa AMC, Longo C and Zeni M. Caracterização de filmes de poli(cloreto de vinila) biodegradados em aterro sanitário II.In: Anais do XI Simpósio Latino Americano, IX Congresso Iberoamericano de Polímeros; 2008; Lima, Peru. Lima: Pontificia Universidad Catolica del Peru; 2008.

28. American Society for Testing Materials - ASTM. D3418-08: Standard Test Method for Transition Temperatures and Enthalpies of Fusion and Crystallization of Polymers by Differential Scanning Calorimetry. ASTM.

29. Vander Wal A, Mulder JJ and Gaymans RJ. Facture of polypropylene: 2. The effect of crystallinity. Polymer. 1998; 39:5477-5481.

30. Sudhakar M, Doble M, Sriyutha MP and Venkatesan R. Marine microbe mediated biodegradation of low and high density polyethylenes. International Biodeterioration and Biodegradation. 2008; 61:203-213. http://dx.doi.org/10.1016/j.ibiod.2007.07.011

31. Sudhakar M, Trishul A, Doble M, Suresh K, Syed J, Umadevi VR et al. Biofouling and biodegradation of polyolefins in ocean waters. Polymer Degradation and Stability. 2007; 92:1743-1752. http://dx.doi. org/10.1016/j.polymdegradstab.2007.03.029

32. Cacciari I, Quatrini P, Zirletta G, Mincione E, Vinciguerra V, Lupatelli P et al. Isotactic polyproplene biodegradation by a microbial community: physicochemical characterization of metabolites produced. Applied Environmental Microbiology. 1993; 59:3695-3700.

33. Liang CY and Pearson FG. Infrared spectra of crystalline and stereoregular polymers. Part I. Polypropylene. Journal of Molecular Spectroscopy. 1960; 5:290-306. http://dx.doi.org/10.1016/0022-2852(61)90094-7 
34. Paukkeri R and Lehtinen A. Thermal behaviour of polypropylene fractions: 1.Influence of tacticity and molecular weight on crystallization and melting behaviour. Polymer. 1993; 34:4075-4082. http://dx.doi. org/10.1016/0032-3861(93)90669-2

35. Bockhorn H, Hornung A, Hornung U, Shawaller D. Kinetic study on the thermal degradation of polypropylene and polyethylene. Journal of Analytical Applied Pyrolysis. 1999; 48:93-109. http://dx.doi.org/10.1016/ S0165-2370(98)00131-4

36. Gao Z, Taneko T, Amasaki I and Nakada M. A kinetic study on thermal degradation of polypropylene. Polymer Degradation and Stability. 2003; 80:269-74. http://dx.doi.org/10.1016/S0141-3910(02)00407-X

37. Grisa AMC and Zeni M. Análise termogravimétrica de polímero commoditie polipropileno (PP) em aterro sanitário. Revista Iberoamericana de Polímeros. 2008; 9:19-24.

38. Suat U, Ahmet R, Ozkan JY and Selhan K. The influence of the waste ethylene vinyl acetate copolymer on the thermal degradation of the waste polypropylene. Fuel Processing Technology. 2008; 89(11):1201-1206. http://dx.doi.org/10.1016/j.fuproc.2008.05.010

39. Chawla S, Ghosch AK, Ahmad S and Avasthi DK. Swift heavy ion induced structural and chemical changes in BOPP film. Nuclear Instruments and Methods in Physics Research B. 2006; 244:248-251. http://dx.doi. org/10.1016/j.nimb.2005.11.159

40. Wallstrom S and Karlsson S. Biofilms on silicone rubber insulators; microbial composition and diagnostics of removal by use of ESEM/EDS. Composition of biofilms infecting silicone rubber insulators. Polymer Degradation and Stability. 2004; 85:841-846. http://dx.doi.org/10.1016/j. polymdegradstab.2004.02.014

41. Wallstrom S, Stromberg E and Karlsson S, Microbiological growth testing of polymeric materials: an evaluation of new methods. Polymer Testing. 2005; 88(3):3394-400.
42. Zhu X, Yan D and Fang Y.FTIR Spectroscopic Study of the Conformational Change of Isotactic Polypropylene during the Crystallization Process Journal of Physical Chemistry B. 2001; 105:12461.

43. Parthasarthy G and Kannan RM. Rheooptical Fourier transform infrared spectroscopy of the deformation behavior in quenched and slow-cooled isotactic polypropylene films Journal of Polymer Science Part B: Polymer Physics. 2002; 40(22):2539-2551. http://dx.doi.org/10.1002/polb.10304

44. Luongo JP. Infrared study of polypropylene. Journal of Applied Polymer Science.1960; 9(3):302-309. http://dx.doi.org/10.1002/ app.1960.070030907

45. Carvalho LB. Produção de polipropileno bi-orientado (Bopp):tecnologia e aplicações. [dissertação]. Bragança: Escola Superior de Tecnologia e de Gestão de Bragança; 2008.

46. Ring $M$ and Tudos F. Thermal oxidation of polyethylene and polypropylene: effects of chemical structure and reaction condition on oxidation process. Progress in Polymer Science. 1990; 15:217-262. http:// dx.doi.org/10.1016/0079-6700(90)90029-Z

47. Mahlberg R, Niemi HEM, Denes F and Rowell RM. Effect of oxygen and hexamethyldisiloxane plasmaon morphology, wettability and adhesion properties of polypropylene and lignocellulosics. International Journal Adhesion and Adhesives. 1998; 18:283-297. http://dx.doi.org/10.1016/ S0143-7496(98)00007-4

48. Arkatkar A, Juwarkar A, Bhaduri S, Uppara PV and Doble M. Growth of Pseudomonas and Bacillus biofilms on pretreated polypropylene surface. International Biodeterioration and Biodegradation. 2010; 64:530-536. http://dx.doi.org/10.1016/j.ibiod.2010.06.002 